\title{
PDLIM2 wt Allele
}

National Cancer Institute

\section{Source}

National Cancer Institute. PDLIM2 wt Allele. NCI Thesaurus. Code C105696.

Human PDLIM2 wild-type allele is located in the vicinity of $8 \mathrm{p} 21.3$ and is approximately 20

$\mathrm{kb}$ in length. This allele, which encodes PDZ and LIM domain protein 2, plays a role in cytoskeletal processes involved in cell adhesion. 